\title{
Influence of Enriched Spent Mushroom Substrate on Growth and Yield of Radish (Raphanus sativus L.)
}

\author{
Pritam Anantrao Bhosale, A. C. Jadhav ${ }^{*}$ and D. H. Phalke \\ Department of Plant Pathology and Agricultural Microbiology, College of Agriculture, Pune, \\ Mahatma Phule Krishi Vidyapeeth, Maharashtra State, India \\ *Corresponding author
}

\begin{tabular}{l} 
Key w or d s \\
Spent Mushroom \\
Substrate, \\
Biofertilizers, \\
Enrichment, Radish, \\
Yield \\
\hline Article Info \\
\hline $\begin{array}{l}\text { Accepted: } \\
\text { 04 December } 2020 \\
\text { Available Online: } \\
\text { 10 January } 2021\end{array}$ \\
\hline
\end{tabular}

\section{Introduction}

Radish (Raphanus sativus L.) is grown for its young tender fusiform root (Brickell, 1992). For the production of good quality radish, optimum nutrition through organic, inorganic and bio-fertilizers are essential for sustainable production. Organic agriculture practices rely upon recycling of crop residues, animal manure, farm organic residues and wastes etc. (Choudhary et al., 2002). The substrate released after mushroom crop harvest, better known as "Spent Mushroom Substrate" (SMS) is also the subject of great importance (Tewari, 2007). The SMS possesses the quality of good organic manure for raising healthy crops of cereals, fruits, vegetables and ornamental plants, in addition to its ability of reclaiming the contaminated soil (Ahlawat and Sagar, 2007). Therefore the quality of spent mushroom substrate can be improved by enriching it with biofertilizers. In order to produce high quality compost, biofertilizers promotes growth by increasing the availability of primary nutrients to the host plant. Also they improve soil structure improving soil fertility (Sudjana et al., 2017).

Enriched SMS is capable of improving the physical, biological and chemical properties 
of soil when it is added to the soil. Also it increases the population of beneficial microorganisms in soil which are necessary for plant growth and good yields. It also minimizes the use of chemical fertilizers (Gumus and Seker, 2017). Keeping this in view, the experiment on influence of enriched spent mushroom substrate (SMS) on growth and yield of radish (Raphanus sativus L.) was undertaken.

\section{Materials and Methods}

\section{Experimental details}

A field experiment was conducted to study the influence of enriched spent mushroom substrate on growth and yield of radish (Raphanus sativus L.) on local variety during Rabi 2019 with three replications and eight treatments at a spacing of $30 \mathrm{~cm} \mathrm{X} 15 \mathrm{~cm}$ in Randomised Block Design at the Plant Pathology Research Farm, College of Agriculture, Pune with treatments detailed below.

\section{Treatment details}

$\mathrm{T}_{1}-\mathrm{SMS}+$ Azotobacter $(\mathrm{AZT})$

$\mathrm{T}_{2}-\mathrm{SMS}+$ Phosphate Solubilizing Bacteria (PSB)

$\mathrm{T}_{3}-\mathrm{SMS}+$ Potash Mobilizing Bacteria (KMB)

$\mathrm{T}_{4}-\mathrm{SMS}+$ Consortium of $\mathrm{AZT}+\mathrm{PSB}+$ $\mathrm{KMB}$

$\mathrm{T}_{5}-\mathrm{FYM}+$ Consortium of $\mathrm{AZT}+\mathrm{PSB}+$ KMB

$\mathrm{T}_{6}-\mathrm{SMS}(20 \mathrm{t} / \mathrm{ha})$

$\mathrm{T}_{7}-\mathrm{FYM}(20 \mathrm{t} / \mathrm{ha})$

$\mathrm{T}_{8}$ - Absolute control

The fresh weight of plant, leaves and roots was recorded immediately after harvest of plant. Dry matter weight of root was also recorded.

\section{Enrichment of SMS and FYM}

The SMS and FYM were enriched prior to the application of individual treatments with biofertilizers viz, Azotobacter, PSB and KMB. The enrichment of SMS and FYM was done as per the treatments. Azotobacter, PSB and KMB were enriched @ 10 kg/ha basis. After enrichment, the SMS and FYM were kept for 4 weeks for the proper growth of microorganisms and for improving nutrient status of compost (Shinde et al., 1985) and (Borah Nilay et al., 2014)

\section{Results and Discussion}

\section{Number of leaves per plant}

Among the different treatments, the treatment $\mathrm{T}_{4}$ i.e. SMS + consortium of AZT + PSB + $\mathrm{KMB}$ was found to be the most effective as it recorded significantly highest number of leaves per plant $(10.5,17.73$ and 25.73$)$ at 30 , 45 days of sowing and at time of harvesting respectively over rest of the treatment, followed by the treatment $\mathrm{T}_{5}$ i.e. $\mathrm{FYM}+$ Consortium of AZT + PSB + KMB (9.53, 15.20 and 21.23) respectively (Table 1 , Fig. $1)$. The lowest number of leaves $(6.20,9.23$ and 11.03) at 30, 45 days of sowing and at time of harvesting respectively were recorded in treatment $\mathrm{T}_{8}$ i.e. absolute control. The obtained results were in accordance with Khalid et al., (2015) and Shruthi et al., (2016) concluded that the combination of inorganic, organic and biofertilizers had given good results which attributed to maximum increase in the height of plant and number of leaves in radish crop.

\section{Plant height (cm)}

The treatment $\mathrm{T}_{4}$ i.e. SMS + Consortium of $\mathrm{AZT}+\mathrm{PSB}+\mathrm{KMB}$ was found to be the most effective as it recorded significantly highest plant height $(26.09,35.53$ and $45.20 \mathrm{~cm})$ 
respectively at 30, 45 days of sowing and at time of harvesting over rest of the treatments (Table 2, Fig. 2)., followed by treatment $\mathrm{T}_{5}$ i.e. FYM + Consortium of AZT + PSB + $\operatorname{KMB}(24.15, \quad 31.80$ and $41.33 \mathrm{~cm})$ respectively at 30,45 days of sowing and at time of harvesting. The lowest plant height $(14.06,18.03$ and $23.02 \mathrm{~cm})$ was recorded in treatment $\mathrm{T}_{8}$ i.e. Absolute control at 30, 45 days of sowing and at time of harvesting. The obtained results are in accordance with Roshni et al., (2019) and Naik and Sreedhar (2019) who reported that application of biofertilizers PSB + KSB + Azospirillum + Azotobacter + VAM combination with RDF recorded the highest plant height.

Table.1 Influence of enriched spent mushroom substrate on number of leaves at 30, 45 DAS and at harvest of crop

\begin{tabular}{|c|c|c|c|c|}
\hline \multicolumn{5}{|c|}{ Number of leaves/plant } \\
\hline Tr. No. & Treatment details & $30 \mathrm{DAS}$ & 45 DAS & At Harvest \\
\hline $\mathbf{T}_{1}$ & $\mathrm{SMS}+$ Azotobacter $(\mathrm{AZT})$ & 8.70 & 14.97 & 20.10 \\
\hline $\mathbf{T}_{2}$ & SMS+ Phosphate Solubilizing Bacteria (PSB) & 7.90 & 12.70 & 16.57 \\
\hline $\mathbf{T}_{3}$ & SMS+ Potash Mobilizing Bacteria (KMB) & 8.13 & 13.53 & 18.53 \\
\hline $\mathbf{T}_{4}$ & SMS+ Consortium of AZT+ PSB+ KMB & 10.50 & 17.73 & 25.73 \\
\hline $\mathbf{T}_{5}$ & FYM+ Consortium of AZT+ PSB+ KMB & 9.53 & 15.20 & 21.23 \\
\hline$T_{6}$ & SMS (20 t/ha) & 7.67 & 11.83 & 15.03 \\
\hline $\mathbf{T}_{7}$ & FYM (20 t/ha) & 7.17 & 11.37 & 14.20 \\
\hline $\mathbf{T}_{8}$ & Absolute control & 6.20 & 9.23 & 11.03 \\
\hline & $\operatorname{SEm}( \pm)$ & 0.30 & 0.55 & 0.77 \\
\hline & CD at $5 \%$ & 0.90 & 1.67 & 2.33 \\
\hline
\end{tabular}

Table.2 Influence of enriched spent mushroom substrate on plant height at 30, 45 DAS and at harvest of crop

\begin{tabular}{|c|c|c|c|c|}
\hline \multicolumn{5}{|c|}{ Plant height $(\mathbf{c m})$} \\
\hline Tr. No & Treatment details & 30 DAS & 45 DAS & At Harvest \\
\hline $\mathbf{T}_{1}$ & $\mathrm{SMS}+$ Azotobacter $(\mathrm{AZT})$ & 22.28 & 29.35 & 37.59 \\
\hline $\mathbf{T}_{2}$ & SMS+ Phosphate Solubilizing Bacteria (PSB) & 19.82 & 24.93 & 31.84 \\
\hline $\mathbf{T}_{3}$ & SMS+ Potash Mobilizing Bacteria (KMB) & 20.55 & 26.50 & 33.36 \\
\hline $\mathbf{T}_{4}$ & SMS+ Consortium of AZT+ PSB+ KMB & 26.09 & 35.53 & 45.20 \\
\hline $\mathbf{T}_{5}$ & $\mathrm{FYM}+$ Consortium of $\mathrm{AZT}+\mathrm{PSB}+\mathrm{KMB}$ & 24.15 & 31.80 & 41.33 \\
\hline $\mathbf{T}_{6}$ & SMS (20 t/ha) & 18.55 & 24.23 & 30.50 \\
\hline $\mathbf{T}_{7}$ & FYM (20 t/ha) & 17.71 & 22.72 & 29.27 \\
\hline$T_{8}$ & Absolute control & 14.06 & 18.03 & 23.02 \\
\hline & SEm $( \pm)$ & 0.57 & 0.78 & 1.01 \\
\hline & CD at $5 \%$ & 1.73 & 2.37 & 3.05 \\
\hline
\end{tabular}


Table.3 Influence of enriched spent mushroom substrate on root length and root diameter of radish $(\mathrm{cm})$

\begin{tabular}{|c|c|c|c|}
\hline Tr. No & Treatment details & $\begin{array}{l}\text { Root length } \\
\text { (cm) }\end{array}$ & $\begin{array}{l}\text { Root diameter } \\
\text { (cm) }\end{array}$ \\
\hline $\mathbf{T}_{1}$ & SMS + Azotobacter $(\mathrm{AZT})$ & 34.57 & 3.58 \\
\hline $\mathbf{T}_{2}$ & SMS+ Phosphate Solubilizing Bacteria (PSB) & 31.20 & 3.10 \\
\hline $\mathbf{T}_{3}$ & SMS+ Potash Mobilizing Bacteria (KMB) & 33.13 & 3.40 \\
\hline $\mathbf{T}_{4}$ & SMS+ Consortium of AZT+ PSB+ KMB & 42.35 & 4.24 \\
\hline $\mathbf{T}_{5}$ & FYM+ Consortium of AZT+ PSB+ KMB & 38.93 & 3.83 \\
\hline $\mathbf{T}_{6}$ & SMS (20 t/ha) & 28.23 & 2.87 \\
\hline $\mathbf{T}_{7}$ & FYM (20 t/ha) & 27.23 & 2.72 \\
\hline $\mathbf{T}_{8}$ & Absolute control & 21.73 & 2.02 \\
\hline \multicolumn{2}{|r|}{ SEm ( $( \pm)$} & 1.04 & 0.13 \\
\hline \multicolumn{2}{|r|}{ CD at $5 \%$} & 3.16 & 0.38 \\
\hline
\end{tabular}

Table.4 Influence of enriched spent mushroom substrate on fresh weight of whole plant, fresh weight of leaves, fresh weight of roots and dry matter weight of roots of radish $(\mathrm{g})$

\begin{tabular}{|c|c|c|c|c|c|}
\hline $\begin{array}{l}\text { Tr. } \\
\text { No. }\end{array}$ & Treatment details & $\begin{array}{c}\text { Fresh } \\
\text { weight } \\
\text { of plant } \\
\text { (g) }\end{array}$ & $\begin{array}{c}\text { Fresh } \\
\text { weight } \\
\text { of leaves } \\
\text { (g) }\end{array}$ & $\begin{array}{c}\text { Fresh } \\
\text { weight of } \\
\text { root }(g)\end{array}$ & $\begin{array}{c}\text { Dry } \\
\text { weight } \\
\text { of plant } \\
\text { (g) }\end{array}$ \\
\hline $\mathbf{T}_{1}$ & SMS + Azotobacter $(\mathrm{AZT})$ & 229.93 & 52.90 & 176.10 & 39.15 \\
\hline $\mathbf{T}_{2}$ & SMS+ Phosphate Solubilizing Bacteria(PSB) & 208.97 & 39.20 & 168.90 & 27.01 \\
\hline $\mathbf{T}_{3}$ & SMS+ Potash Mobilizing Bacteria (KMB) & 217.70 & 44.30 & 172.67 & 32.93 \\
\hline $\mathbf{T}_{4}$ & SMS+ Consortium of AZT+ PSB+ KMB & 375.41 & 87.07 & 288.11 & 52.36 \\
\hline $\mathbf{T}_{5}$ & FYM+ Consortium of AZT+ PSB+ KMB & 327.80 & 76.03 & 251.77 & 45.50 \\
\hline $\mathbf{T}_{6}$ & SMS (20 t/ha) & 189.13 & 34.29 & 154.84 & 25.91 \\
\hline $\mathbf{T}_{7}$ & FYM (20 t/ha) & 183.20 & 31.83 & 151.37 & 23.35 \\
\hline $\mathbf{T}_{8}$ & Absolute control & 123.90 & 23.43 & 100.47 & 18.41 \\
\hline \multicolumn{2}{|r|}{ SEm ( $( \pm)$} & 1.69 & 1.43 & 1.97 & 1.15 \\
\hline \multicolumn{2}{|r|}{ CD at $5 \%$} & 5.12 & 4.34 & 5.98 & 3.50 \\
\hline
\end{tabular}

Fig.1 Influence of enriched spent mushroom substrate on number of leaves at 30, 45 DAS and at harvest of crop

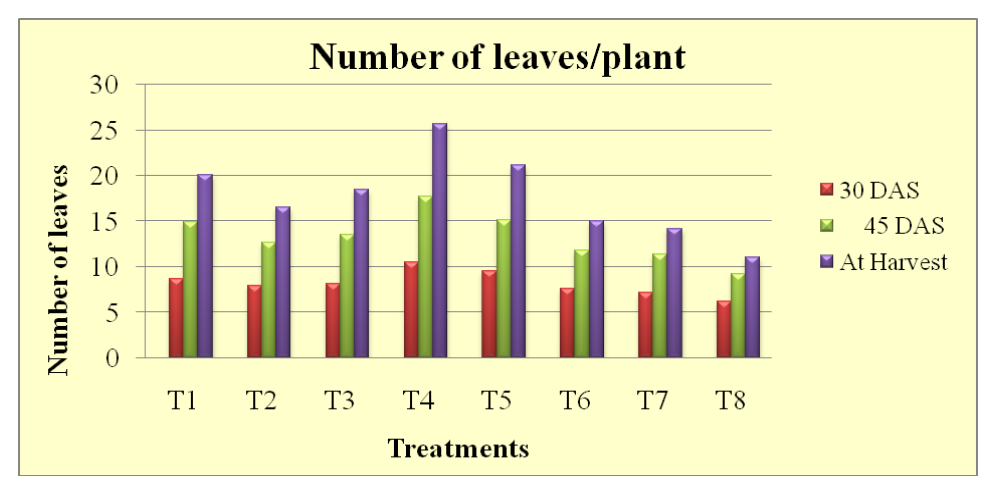


Fig.2 Influence of enriched spent mushroom substrate on plant height (cm) at 30, 45 DAS and at harvest of crop

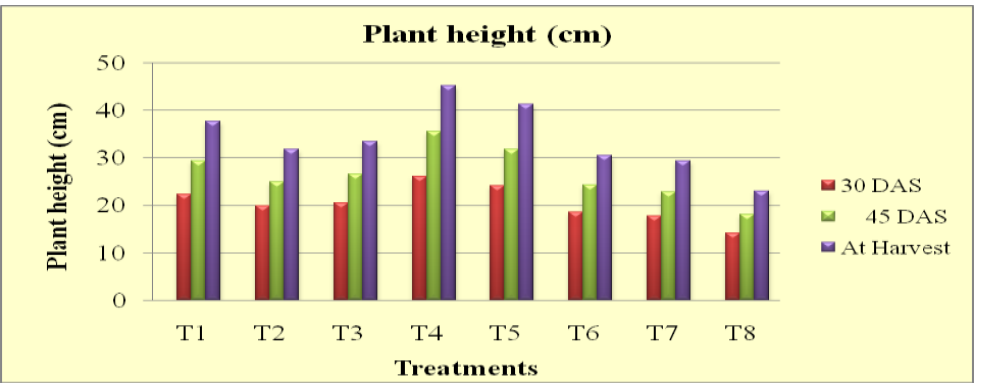

Fig.3 Influence of enriched spent mushroom substrate on root length and diameter $(\mathrm{cm})$ of radish

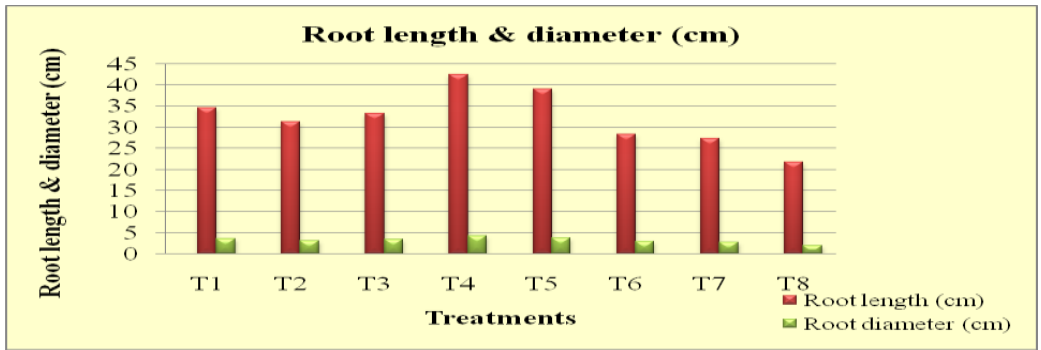

Fig.4 Influence of enriched spent mushroom substrate on fresh wt. of plant, leaves, root and dry wt. of plant $(\mathrm{g})$

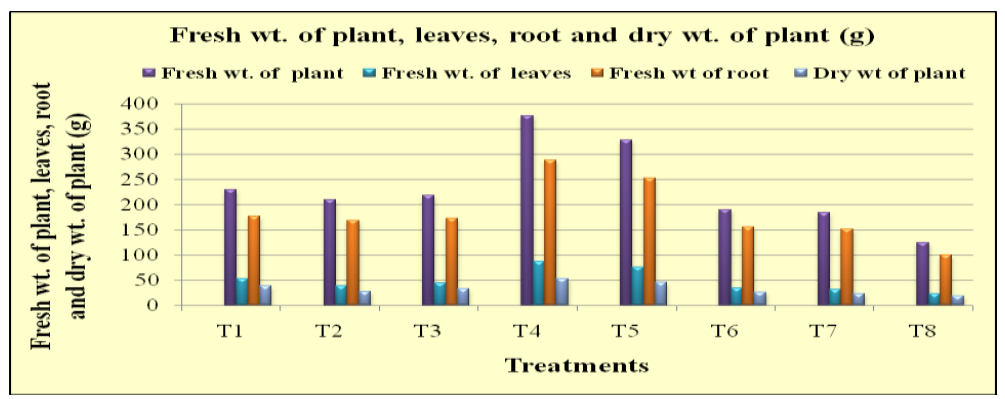

Fig.5 Influence of enriched spent mushroom substrate on root yield (kg/plot) and root yield (t/ha) of radish

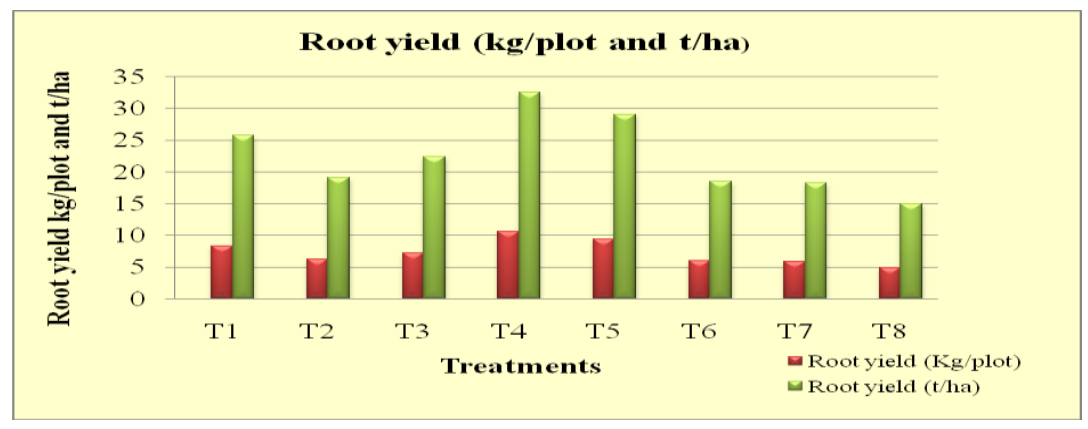


Plate.1 Influence of enriched SMS on yield parameters of radish in different treatments

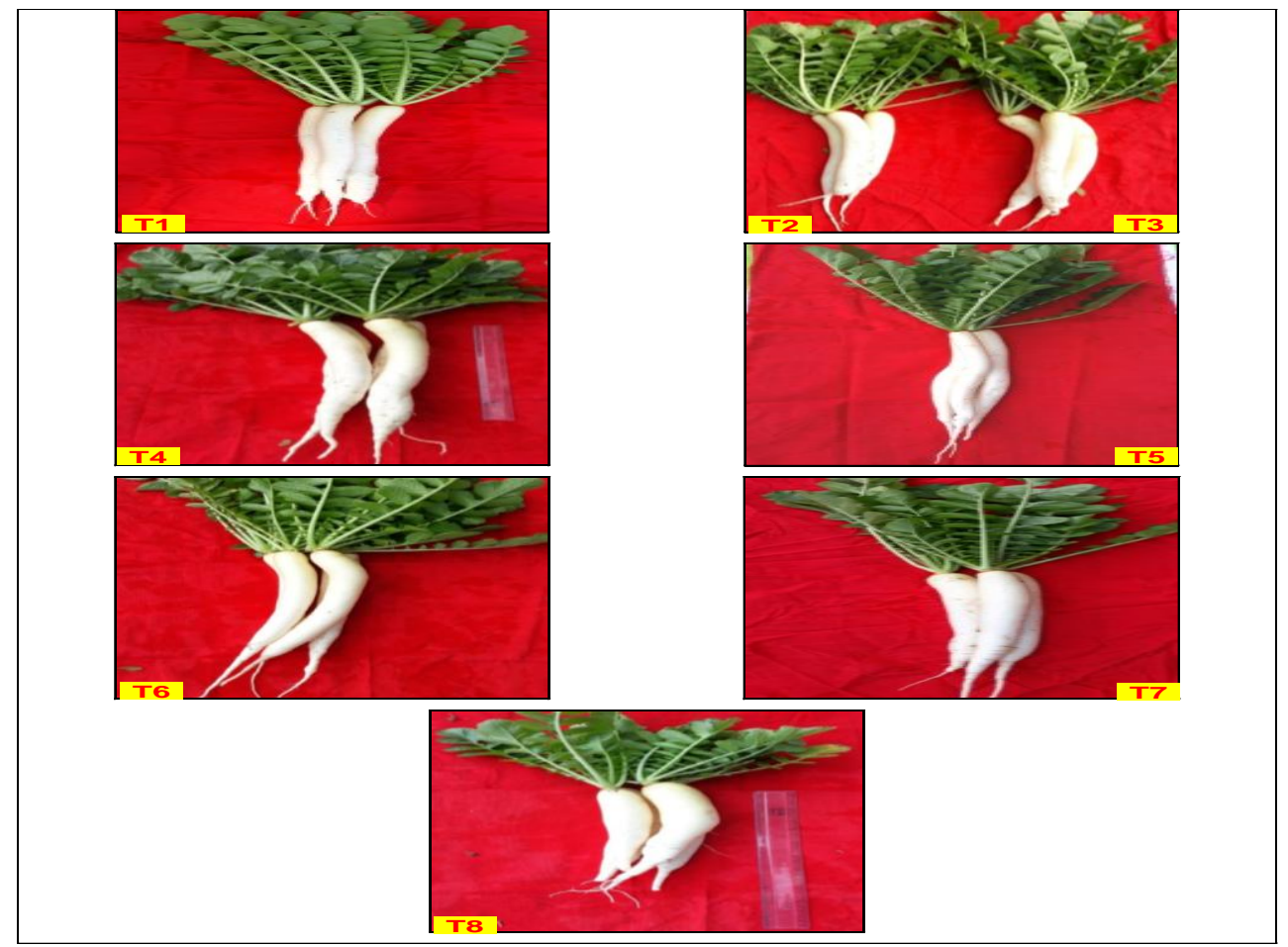

\section{Root length at harvest (cm)}

The significantly highest root length $(42.35$ $\mathrm{cm})$ at time of harvest over rest of the treatments was recorded by the treatment $\mathrm{T}_{4}$ i.e. SMS + Consortium of AZT + PSB + $\mathrm{KMB}$ and was found to be the most effective followed by treatment $\mathrm{T}_{5}$ i.e. FYM + Consortium of AZT + PSB + KMB (38.93 $\mathrm{cm})$ (Table 3, Fig. 3). The lowest root length $(21.73 \mathrm{~cm})$ was recorded in treatment $\mathrm{T}_{8}$ i.e. Absolute control at the time of harvest. These results are comparable with the reports of Vithwel Kanaujia (2013); Khalid et al., (2015) and Gautum Singh (2018) who also reported increase in root length in carrot and radish crops respectively.

\section{Root diameter at harvest $(\mathrm{cm})$}

The data presented in Table 3, Fig. 3, showed that among the different treatments, treatment $\mathrm{T}_{4}$ i.e. SMS + Consortium of AZT $+\mathrm{PSB}+$
KMB was found to be the most effective as it recorded significantly highest root diameter $(4.24 \mathrm{~cm})$ at time of harvest over rest of the treatments followed by treatment $\mathrm{T}_{5}$ i.e. FYM + Consortium of AZT + PSB + KMB (3.83 $\mathrm{cm})$. The lowest root diameter $(2.02 \mathrm{~cm})$ was recorded in treatment $T_{8}$ i.e. absolute control at the time of harvest. The results obtained are in agreement with Khalid et al., (2015), Shruthi et al., (2016) and Jaishankar (2018) who concluded that the combination of inorganic, organic and biofertilizers attributed to the increase in the diameter/thickness/root girth of main root in radish.

\section{Fresh weight of plant (g)}

Among the different treatments, the treatment $\mathrm{T}_{4}$ i.e. SMS + consortium of AZT + PSB + KMB was found to be the most effective as it recorded significantly highest fresh weight of plant $(375.41 \mathrm{~g})$ at time of harvest over rest of the treatments followed by treatment $\mathrm{T}_{5}$ i.e. 
$\mathrm{FYM}+$ Consortium of AZT + PSB + KMB $(327.80 \mathrm{~g})$. The lowest fresh weight of plant $(123.90 \mathrm{~g})$ was recorded in treatment $\mathrm{T}_{8}$ i.e. Absolute control at the time of harvest (Table 4, Fig.4). These findings are in line with reports of Singh et al., (2017), Kirad et al., (2010), Vithwel Kanaujia (2013) in carrot and Khalid et al., (2015) and Gautum Singh (2018) in radish crop.

\section{Fresh weight of leaves (g)}

The data presented in Table 4, Fig. 4 showed that among the different treatments, treatment $\mathrm{T}_{4}$ i.e. SMS + Consortium of AZT + PSB + KMB was found to be the most effective as it recorded significantly highest fresh weight of leaves $(87.07 \mathrm{~g})$ at time of harvest over rest of the treatments followed by treatment $T_{5}$ i.e. $\mathrm{FYM}+$ Consortium of AZT + PSB + KMB $(76.03 \mathrm{~g})$. The lowest fresh weight of leaves $(23.43 \mathrm{~g})$ was recorded in treatment $\mathrm{T}_{8}$ i.e. absolute control at the time of harvest. Similar trend of results was also reported by Espiritu (2011) who stated that fresh and dry weight of pechay was significantly increased by combined inoculation of Azotobacter sp. and T.harzianum. The results are comparable with those of Singh et al., (2017) in carrot; Khalid et al., (2015) and Gautum Singh (2018) in radish crop.

\section{Fresh weight of root $(\mathrm{g})$}

The data shown in Table 4, Fig. 4 showed that among the different treatments, treatment $\mathrm{T}_{4}$ i.e. SMS + Consortium of AZT + PSB + $\mathrm{KMB}$ was found to be the most effective and recorded significantly highest fresh weight of root $(288.11 \mathrm{~g})$ at time of harvest over rest of the treatments followed by treatment $\mathrm{T}_{5}$ i.e. $\mathrm{FYM}+$ Consortium of AZT + PSB + KMB $(251.77 \mathrm{~g})$. The lowest fresh weight of root $(100.47 \mathrm{~g})$ was recorded in treatment $\mathrm{T}_{8}$ i.e. absolute control at the time of harvest. The results are comparable with Khalid et al.,
(2015) and Shruthi et al., (2016) who also concluded that the combination of inorganic, organic and bio fertilizers had attributed to the increase in the leaf: root weight ratio, fresh weight of root and ultimately yield in radish.

\section{Dry matter weight of root (g)}

The data (Table 4, Fig. 4) showed that among the different treatments, treatment $\mathrm{T}_{4}$ i.e. SMS + Consortium of AZT + PSB + KMB was found to be the most effective as it recorded significantly highest dry weight of plant $(52.36 \mathrm{gm})$ over rest of the treatments followed by treatment $\mathrm{T}_{5}$ i.e. FYM + Consortium of AZT + PSB + KMB (45.50 g). The lowest dry weight of plant (18.41 g) was recorded in treatment $\mathrm{T}_{8}$ i.e. absolute control. The obtained results are in accordance with Roshni et al., (2019) who concluded that application of biofertilizers PSB + KSB + Azospirillum + Azotobacter + VAM combination with $100 \%$ RDF recorded the highest dry matter weight of root $(34.25 \mathrm{~g})$ in carrot.

\section{Root Yield (kg/plot)}

The data presented in Table 4, Fig. 4 showed that among the different treatments, treatment $\mathrm{T}_{4}$ i.e. SMS + Consortium of AZT + PSB + $\mathrm{KMB}$ was found to be the most effective as it recorded significantly highest root yield $(10.52 \mathrm{~kg} / \mathrm{plot})$ over rest of the treatments followed by treatment $\mathrm{T}_{5}$ i.e. FYM + Consortium of AZT + PSB + KMB (9.39 $\mathrm{kg} / \mathrm{plot})$. The lowest root yield $(4.82 \mathrm{~kg} / \mathrm{plot})$ was recorded in treatment $\mathrm{T}_{8}$ i.e. Absolute control.

\section{Root Yield (t/ha)}

Among all the different treatments, the treatment $\mathrm{T}_{4}$ i.e. $\mathrm{SMS}+$ Consortium of AZT + $\mathrm{PSB}+\mathrm{KMB}$ was found to be the most effective as it recorded significantly highest 
root yield (32.48 t/ha) over rest of the treatments followed by treatment $\mathrm{T}_{5}$ i.e. FYM + Consortium of AZT + PSB + KMB (28.98 $\mathrm{t} / \mathrm{ha})$. The lowest root yield (14.88 $\mathrm{t} / \mathrm{ha})$ was recorded in treatment $\mathrm{T}_{8}$ i.e. absolute control (Table 5, Fig. 5, Plate 1). Similar trend of results was also reported by Seran et al., (2017) who reported that higher marketable radish yield was obtained with application of compost $20 \mathrm{t} / \mathrm{ha}+$ half dose of NPK fertilizers.

In conclusion, the experiment showed that SMS could be converted into enriched compost as a value added product rich in plant nutrient by enriching with biofertilizers like Azotobacter, PSB and KSB. Microbial consortium enhances the process of composting and enriches nutrient content to the soil. Application of SMS + Consortium of $\mathrm{AZT}+\mathrm{PSB}+\mathrm{KMB}\left(\mathrm{T}_{4}\right)$ influence on growth and yield parameters of radish crop.

\section{Acknowledgements}

Authors are thankful to the staff of the Professor of Plant Pathology and Agril. Microbiology Section, Soil Science and Agril. Chemistry Section, College of Agriculture, Pune (MS) for providing necessary facilities during the investigations.

\section{References}

Ahlawat, O. P. and Sagar, M. P. 2007. Spent mushroom substrate-properties and recycling for beneficial purpose. In Fortiners, Mushroom Biotechnology, National Research Centre for Mushroom, Solan. India, pp. 314-334.

Borah Nilhay et. al., 2014. Enrichment of compost through microbial inoculation - Effect on quality. Int. J. Curr. Res., 6 (08), 8026-8031.

Brickell, C. (ed). 1992. The Royal Horticultural Society Encyclopedia of
Gardening. Londan: Dorling Kindersley. Pp. 356-357. ISBN. 978086318-979-1.

Choudhary et al., 2002. Role of growth hormones in chilies: A review. Agric. Rev., 23 (2): 145-148

Dixon, G. R. 2007. Vegetable Brassicas and related Crucifers (Print). Crop Production Science in Horticulture. 14. Wallingford: CAB International. ISBN 978-1-84593-138-4.

Espiritu, B. N. 2011. Composting and microbial inoculation of coconut coir dust-chicken manure mixture for organic fertilizer use, Crop protection newsletter 36 (1): 47-56 April 2011. Mushroom, Solan. India, pp. 314-334.

Gautam Singh et al., 2018. Effect of fertilizer and biofertilizers on vegetative growth, yield and quality of radish. Annals of Plant and Soil Research, pp 20-23 (2018).

Gumus Ilknur and Cevdet Seker. 2017. Effect of spent mushroom compost application on the physiochemical properties of a degraded soil. Solid Earth, 8, 1153-1160.

Jaisankar, P. 2018. Effect of integrated nutrient management of growth and yield of radish cv. Pusa Chetki. Int. J. Curr. Microbiol. App. Sci. (2018) 7(11): 461-466.

Kirad et al.,2010. Integrated nutrient management on growth, yield and quality of carrot. Karnataka J. Agril. Sci. 23(3): 542-543.

Mohammad Khalid et al., 2016. Studies on the effect of integrated nutrient management on yield attributing characters of radish (Raphanus sativus L.). Res. Environ. Life Sci. 9(1) 129130.

Naik, M. R. and D. Sreedhar. 2018. Growth and yield response of radish cv. Pusa Himani to integrated nutrient management practices. Int. J. of Agril. 
Env. and Bio. 3(03); 2018.

Roshni et al., 2019. Studies on biofertilizers and inorganics on growth and yield of carrot. J. of Pharamacognosy and Phtyochemistry. 8(2): 1559-1562.

Shinde et al., 1985. Effect of enriched city compost with rock phosphate on yield of mung. J. of Maharashtra Agril. Uni., 10(3): 346-347.

Shruti et al., 2016. Effect of biofertilizers on growth and root yield of radish cv Pusa Chetki under hill zone of Karnataka. $J$. of Env. and Ecology, 2016, 34 (4A): 2014-2017.

Singh et al., 2017. Studies on integrated nutrient management on growth, yield and quality of carrot (Daucus carota L.) Int. J. of Agril. Sci .51(8): 21872188
Sudjana et al., 2017. Enrichment of mushroom compost heap quality using Azotobacter and Pseudomonas as a renewable ameliorant. Int. J.of Agril. Inno. and Res., 5(5), ISSN (Online) 2319-1473.

Tewari, R. P. 2004. Mushroom industry and its export potential Indian Horticulture. $18-19$

Thamburaj, S and Singh, N. 2005. Vegetables, Tuber crops and Species. New Delhi: Indian Council of Agriculture Research. pp. 40.

Vithwel Kanujia, S. P. 2013. Integrated nutrient management on productivity of carrot and fertility of soil. SAARC J. of Agril. 11(2): 173-81.

\section{How to cite this article:}

Pritam Anantrao Bhosale, A. C. Jadhav and Phalke, D. H. 2021. Influence of Enriched Spent Mushroom Substrate on Growth and Yield of Radish (Raphanus sativus L.). Int.J.Curr.Microbiol.App.Sci. 10(01): 271-279. doi: https://doi.org/10.20546/ijcmas.2021.1001.033 